\title{
KEPEMIMPINAN TRANSFORMASIONAL DALAM PENINGKATAN MUTU PENDIDIKAN DI MADRASAH TARBIYAH ISLAMIAH (MTI) CANDUANG
}

\author{
Syamsul Qomar \\ Koresponden: Selok Gondang, Kec. Sukodono Kab. Lumajang, Prov. J awa Timur, HP. 081315952730 \\ e-mail: syams_imel@yahoo.co.id. \\ 120
}

\begin{abstract}
From research conducted data showed that transformational leadership has been executed well by leaders in MTI Canduang. This is evidenced by the changes better than ever, morale and motivation of teachers and employees. Factors supporting leadership in MTI Canduang of which is a strong leader, the majority are young, energetic and highly motivated, skilled in the art, the support of all parties. Whereas the inhibiting factor of which is the absence of a permanent dormitory, minimal finances. Models/styles of verbal and non verbal leadership shown by the variety of writing programs that have been created by the leadership as well as attitudes and daily behavior is an example for subordinates. From the findings of this study concluded that transformational leadership has done well in MTI Canduang. Factors supporting leadership more than the barriers. While the verbal and non verbal leadership has been executed well by the existing leaders.
\end{abstract}

Key Words: Kepemimpnan transformasional, peningkatan mutu

\section{PENDAHULUAN}

Berbicara tentang pemimpin (leader) dalam dunia pendidikan merupakan suatu hal yang sangat menarik. Apabila pemimpin mampu melaksanakan visi dan misi lembaga serta bisa menggerakkan semua stakeholders yang ada sesuai dengan tugas dan fungsinya masing-masing, maka lembaga tersebut sudah pasti bisa memenuhi target sesuai dengan visi dan misi yang ada. Dalam bahasa arab, kepemimpinan sering diterjemahkan sebagai Kata tersebut memiliki satu makna (مرادف), sehingga bisa digunakan salah satu dari keempat kata tersebut untuk meterjemahkan kata kepemimpinan.
Sementara itu untuk menyebut istilah kepemimpinan pendidikan, para ahli lebih memilih istilah qiyadah tarbawiyah/ قيادةتربوية(Mujamil Qomar, 2007:268-269).

Menurut Nurkholis (Nurkholis, 2003:119), pada tingkat sekolah, Kepala Sekolah sebagai figur kunci dalam mendorong perkembangan dan kemajuan sekolah. Kepala sekolah tidak hanya memiliki tanggungjawab dan otoritas dalam program-program sekolah, kurikulum dan keputusan personil, tetapi juga memiliki tanggungjawab dalam peningkatan mutu sekolahnya sehingga mencapai target sesuai dengan visi misi sekolah. Kepemimpinan merupakan tanggungjawab dunia maupun 
akhirat. Dalam memimpin seseorang harus mengacu pada kepemimpinan yang telah dicontohkan oleh Rasulullah Saw, karena kepemimpinan Rasulullah telah terbukti sukses dan diakui semua pihak, kawan maupun lawan. Rasulullah Saw merupakan uswah dan qudwah hasanah bagi umat Islam.

Menurut Komariah dan Triana (Aan Komariah dan Cepi Triana, 2010:78), gaya kepemimpinan transformasional hadir menjawab tantangan zaman yang penuh dengan perubahan. Zaman yang dihadapi saat ini bukan zaman ketika manusia menerima segala apa yang menimpanya, tetapi zaman di mana manusia dapat mengkritik dan meminta yang layak dari apa yang diberikannya secara kemanusiaan. Bahkan dalam terminologi Maslow, manusia di era ini adalah manusia yang memiliki keinginan mengaktualisasikan dirinya yang berimplikasi pada bentuk pelayanan dan penghargaan terhadap manusia itu sendiri.

Menurut Encep (Encep Syafrudin Muhyi, 2011:190), kepemimpinan transformasional adalah kemampuan untuk memberi inspirasi dan memotivasi para pengikut untuk mencapai hasil-hasil yang lebih besar dari pada yang direncanakan. Dengan mengungkapkan suatu visi, pemimpin transformasional memberdayakan para pengikut untuk bekerja keras mencapai sasaran yang digambarkan. Visi pemimpin memberikan motivasi bagi pengikut untuk bekerja keras yakni memberikan penghargaan kepada diri sendiri.

Salah satu isu penting dalam penyelenggaraan pendidikan saat ini adalah peningkatan mutu pendidikan. Undang- undang nomor 20 tahun 2003 tentang Sistem Pendidikan Nasional pasal 4 ayat 6 menegaskan bahwa: "Pendidikan diselenggarakan dengan memberdayakan semua komponen masyarakat melalui peranserta dalam penyelenggaraan dan pengendalian mutu layanan pendidikan". Dalam upaya meningkatkan mutu pendidikan atau sekolah, setiap lembaga pendidikan akan selalu berusaha untuk meningkatkan mutu lulusan. Merupakan sesuatu yang mustahil jika pendidikan/sekolah dapat menghasilkan lulusan yang bermutu, akan tetapi tidak melalui proses pendidikan yang bermutu.

Pada tanggal 5 mei 2013 Madrasah Tarbiyah Islamiyah (MTI) Canduang merayakan ulang tahunnya yang ke-85 (Inforkom MTI Canduang 2013). Walaupun usianya sudah tua, MTI Canduang masih terus meraih prestasi dan potensi, masih bisa bertahan dan diminati oleh masyarakat di tengah persaingan dunia pendidikan. Dengan kepemimpinan transformasional yang diterapkan oleh pimpinan di MTI Canduang, maka lembaga ini akan semakin maju dan menjadi lembaga pendidikan yang bermutu tinggi dan semakin diminati oleh masyarakat.

\section{METODE PENELITIAN}

Penelitian ini merupakan penelitian kualitatif. Jenis penelitian studi kasus (case study), karena penelitian akan mendeskripsikan kasus tentang hal-hal objektif (Emzir, 2011:37) yang muncul tentang kepemimpinan transformasional dalam peningkatan mutu pendidikan di MTI Canduang. Data dan sumber data penelitian ini berupa data primer yaitu Ketua Yayasan, Raisul Madrasah, Kepala 
Sekolah/Madrasah dan data sekunder yaitu Guru, Karyawan, Wali murid/santri, Siswa/ santri dan Tokoh masyarakat.

\section{PEMBAHASAN}

\section{Gambaran Umum Lokasi Penelitian}

Madrasah Tarbiyah Islamiyah (MTI) Canduang yang beralamat di jln. Syeikh Sulaiman Arrasuli, Pakan Kamis, Lubuak Aua, Canduang Koto Laweh, Kecamatan Canduang, Kabupaten Agam Provinsi Sumatera Barat adalah institusi Pendidikan Islam yang dikembangkan oleh Maulana Syeikh Sulaiman Arrasuli dari halaqah pengajian Thuras (kitab-kitab klasik) di SurauBaru Pakan Kamis Canduang yang beliau tekuni sejak tahun 1908-1928 sepulang belajar dari Mekkah. Tahun 1928 pola halaqah berubah menjadi klasikal dengan memakai meja, kursi, papan tulis dan kapur tulis sebagai sarana belajar. Sebenarnya cikal bakal MTI Canduang adalah sejak tahun 1908. Akan tetapi tahun berdirinya dihitung sejak memakai pola klasikal tahun 1928. MTI Canduang berada di bawah naungan Yayasan Syeikh Sulaiman Arrasuli dan memiliki dua institusi pendidikan, yaitu Madrasah Tsanawiyah Swasta Tarbiyah Islamiah (MTs. TI) Canduang dan Madrasah Aliyah Swasta Tarbiyah Islamiah (MAS. TI) Canduang. Sedangkan masa belajarnya selama 7 tahun.

\section{Visi dan Misi MTI Canduang}

Visi MTI Canduang adalah "Menjadi Lembaga Pendidikan Islam Yang Mewujudkan Intelektual Muda Muslim Yang Tafaqquh
Fiddiin", sedangkan misi MTI Canduang adalah:

a. Menjadikan MTI Canduang sebagai Madrasah yang spesialis Kitab-Kitab Kuning untuk melahirkan kader-kader ulama', para muballighlah yang handal.

b. Menyiapkan lulusan yang memiliki pengetahuan dan kemampuan dalam kajian-kajian ke-Islaman yang merujuk kepada kitab-kitab klasik (kitab kuning).

c. Menyelenggarakan pendidikan dan pengajaran yang berbasis akidah dan akhlak sehingga melahirkan sumberdaya manusia yang memiliki integritas kepribadian Muslim.

d. Mengembangkan pendidikan yang mengintegrasikan kajian ayat-ayat qur'aniyah (wahyu) dengan ayat-ayat kauniyah (alam).

e. Mengupayakan penyelenggaraan pendidikan dengan tiga bahasa: Bahasa Arab, Bahasa Inggris, Bahasa Indonesia dan berbasis Information communication Technology (ICT).

f. Menerapkan pendidikan yang efektif, efesien dan konsisten, mengacu kepada standar mutu nasional.

\section{TEMUAN PENELITIAN}

Istilah kepemimpinan transformasional terdiri dari dua suku kata yaitu leadership "kepemimpinan" dan transforma tion "transformasional" (SudarmanDanim, 2005:53). Berdasarkan teori yang telah dikemukakan oleh Bass dan Avolio, bahwasanya pemimpin transformasional mempunyai 
empat dimensi yang disebut dengan "The Four I" yaitu: Idealized Influence, Inspirational Motivation, Intelectual Stimulation, dan Individual Consideration.

Pertama, pemimpintransformasional harus mempunyai karakter Idealized Influence, artinya mempunyai pengaruh atau keyakinan yang kuat. Ada beberapa faktor yang membuat seorang pemimpin itu berpengaruh, di antaranya karena pemimpin tersebut dipilih secara demokratis, ahli dibidangnya, berpengalaman, energik dan lain-lain. Ada hal menarik dalam proses pemilihan pimpinan di MTI Canduang. Proses pemilihan pimpinan di sana tidak sama seperti di tempat-tempat lain pada umumnya terutama di swasta yang kesannya asal-asalan. Akan tetapi di MTI Canduang telah melaksanakan pemilihan secara profesional. Pemilihan Rais dan Wakil Rais dilakukan oleh Yayasan. Begitu juga penseleksian Kepala Sekolah dan Wakil Kepala yang diusulkan oleh Raisul Madrasah kepada Yayasan.

Sebagai contoh pemilihan Kepala Aliyah pengganti dari Drs. H. Muhammad Nur yang telah pensiun dari jabatannya beberapa bulan yang lalu. Tugas untuk mencari calon kepala tersebut berada di tangan RaisulMadrasah yang sebelumnya koordinasi dulu dengan dewan guru dan karyawan. Ada beberapa calon yang direkomendasikan oleh dewan guru kepada Rais. Untuk selanjutnya diteruskan kepada Yayasan. Sesampainya di Yayasan tidak langsung disetujui rekomendasi dari Rais tersebutkarena masih dipelajari dan diproses lagi sesuai dengan standar yang telah ditetapkan oleh Yayasan. Akhirnya Yayasan menetapkan Ust. Zulkifli, S.Pd.I, MA, sebagai kepala madrasah tingkat Aliyah.

Penulis memperoleh keterangan tentang alasan terpilihnya Ust. Zulkifli sebagai Kepala MAS. TI Canduang dari Ust. Dt. Muhammad Nazif, S.Ag, sebagai Kepala TU MTI Canduang:

"MTI Canduang ingin berbenah diri supaya kelak bisa berubah dan lebih baik lagi. Langkah pertama yang tempuh salah satunya adalah dengan memilih kepala sekolah yang profesional. Contohnya Ust. Zulkifli, MA selaku Kepala Aliyah, beliau berpengalaman karena masih alumni dan putera Canduang serta gelar akademik yang ia sandang. Beliau juga kreatif dan energik karena masih muda dan belum banyak beban" (Muhammad Nazif : 2 September 2013).

Hal senada juga Penulis peroleh dari Buya H. Amhar Zein Arrasuli selaku Raisul Madrasah di MTI Canduang. Beliau mengatakan;

"Zulkifli itu akan memiliki pengaruh kuat sebagai Kepala Aliyah karena terpilih dengan proses yang panjang dan profesional. Dia energik sesuai dengan umurnya yang masih muda dan sesuai dengan kemampuannya secara akademik maupun pengalamannya selama ini karena telah mengabdi di sini sudah lama sekali" (H. Amhar Zein Arrasuli : 2 September 2013).

Kedua, seorang pemimpin transformasional harus mempunyai jiwa Inspirational Motivation. Artinya seorang pemimpin bisa dikatakan pemimpin yang transformasional 
adalah jika pemimpin tersebut mampu dan bisa untuk menginspirasi dan memotivasi para bawahannya di manapun dan kapanpun dibutuhkan. Di MTI Canduang pemimpin yang ada menjadi inspirator dan motivator bagi guru dan karyawan. Ketua Yayasan juga sering memberikan training dan motivasi, Rais dan pimpinan lainnya selalu hadir. Secara tidak langsung Ketua Yayasan DR. Syukri Iska, M.Ag telah menjadi inspirasi dan motivasi bagi guru dan karyawan di MTI Canduang. Mereka bangga karena yang menjadi Ketua Yayasan seorang Doktor dan mantan Ketua STAIN Batusangkar selama dua periode. Mereka percaya penuh MTI Canduang akan semakin maju, karena STAIN maju pesat ketika dipimpin oleh DR. Syukri Iska, M.Ag, apalagi MTI Canduang merupakan lembaga pendidikan yang jauh lebih kecil apabila dibandingkan dengan STAIN Batusangkar.

Ada terobosan baru tahun 2013 yang dibuat oleh pimpinan di MTI Canduang dalam rangka memotivasi guru dan karyawan supaya lebih semangat lagi. Di antaranya adalah gaji naik beberapa persen, tunjangan bertambah, ada kenaikan gaji berkala. Bagi guru dan karyawan yang berprestasi akan mendapatkan penghargaan dari lembaga yang disertai dengan bonus. Seperti contoh wali kelas yang anak didiknya berhasil juara umum akan mendapatkan penghargaan. Santri yang juara umum juga bebas uang SPP 3 bulan. Begitu juga uang transportasi harian naik hampir mencapai $40 \%$ dan berbeda nominalnya, tergantung jauh dekatnya jarak dari rumah ke Madrasah. Uang transportasi tertinggi hampir mencapai Rp. 30.000,perhari. Uniknya lagi bagi guru/karyawan yang tidak ada tugas/jam mengajar boleh datang ke Madrasah dan tetap mendapatkan uang transportasi asalkan mengisi daftar hadir yang tersedia di kantor. Dengan demikian motivasi untuk datang ke Madrasah semakin besar karena diimbangi dengan penghargaan yang lebih baik dari MTI Canduang.Untuk lebih menguatkan lagi informasi yang penulis peroleh di lapangan, penulis mewawancarai Ust. Alimin Alam yang telah mengabdikan dirinya selama lebih dari 24 tahun dan mengatakan;

"Banyak terobosan baru di tabun 2012/2013 yang dibuat oleh para pemimpin di MTI Canduang ini. Mereka berusaha supaya guru dan karyawan betah di sini dan termotivasi untuk bekerja lebih baik lagi. Di antaranya kenaikan gaji, penghargaan bagi yang berprestasi dan lain-lain sehingga kami merasa nyaman di sini. Perubahan ini baru terlihat beberapa tahun belakangan yang sebelumnya tidak ada. Ini semua karena jajaran pimpinan mengerti dan memahami kebutuhan semua pihak dan berfkir maju ke depan" (Ust. Alimin Alam, 5 September 2013:10.15).

Ketiga, Intelectual Stimulation adalah karakter pemimpin transformatif berikutnya. Maksudnya adalah pemimpin yang transformasional harus mampu memberikan rangsangan intelektualitas pengikutnya supaya bekerja lebih baik lagi dan profesional. Hal ini bukan Cuma dirangsang saja supaya bekerja lebih baik lagi. Akan tetapi pemimpin juga merusaha untuk memenuhi kebutuhankebutuhan karyawan yang berdampak langsung dengan kinerjanya. 
Untuk merangsang intelektualitas guru dan karyawan di MTI Canduang, jajaran pimpinan yang ada membuat berbagai program yang berkaitan langsung dengan intelektualitas dan kemampuan guru dan karyawan. Di antaranya adalah mengundang para pakar dan ahli untuk memberikan pelatihan-pelatihan bagi guru dan karyawan. Bagi guru kitab kuning di datangkan pakar dan ahli kitab kuning yang profesional seperti Prof.Dr. Makmur Syarif selaku Rektor IAIN Imam Bonjol Padang dan masih alumni MTI Canduang. Bahkan dalam waktu dekat ini MTI Canduang akan mendatangkan guru dari Universitas Al-Azhar Kairo di Mesir yang merupakan Universitas tertua di Dunia. Dengan demikian para guru kitab dan santri bisa belajar banyak dari Syeikh yang datang dari Mesir dan mereka dituntut untuk berbicara dengan Bahasa Arab dan dengan sendirinya mereka akan lancar dalam komunikasi Bahasa Arab.

MTI Canduang rutin mengadakan pelatihan Komputer terutama libur Ramadhan bagi guru-guru yang belum bisa menguasainya. Tidak bisa dipungkiri bahwasanya masih banyak guru-guru lama yang belum bisa menguasai komputer. Dengan pelatihan tersebut diharapkan semua guru minimal bisa membuat perangkat pembelajaran dengan komputer yang sebelumnya masih ditulis dengan tangan. Ternyata antusias dari para guru sangat tinggi, bahkan mereka ada yang membeli laptop untuk di rumah. Ketika berada di Madrasah mereka mencari/ mendownload materi-materi yang dibutuhkan untuk pembelajaran dari internet yang disediakan gratis oleh pihak Madrasah. Hal di atas senada dengan ungkapan Ust. Adrian, S.Pd selaku guru TIK dan penanggungjawab Labor Komputer untuk tingkat Aliyah di MTI Canduang yang mengatakan;

"Di sini hampir setiap liburan terutama libur panjang di Bulan Ramadhan diadakan pelatihan komputer untuk guruguru terutama bagi guru yang belum bisa menguasai ilmu komputer dasar. Bagi yang sudah bisa diharapkan untuk menambah pengalaman sekaligus mengisi waktu senggang karena liburan. Di samping mendapatkan ilmu baru, mereka juga memperoleh uang transportasi perharinya. Saya lihat mereka antusias sekali mengikutinya, semangat mereka sangat tinggi dan patut untuk dicontoh"(Ust. Adrian, S.Pd:12 September 2013).

Sedangkan yang keempat yang harus dimiliki oleh pemimpin transformasional adalah Individual Consideration yang berarti pemimpin tersebut harus mempunyai pertimbangann-pertimbangan individual terhadap karyawannya. Akan tetapi pertimbangan-pertimbangan tersebut yang sifatnya positif. Bukan berarti karyawan yang merupakan teman dekat atau masih ada hubungan kerabat diperlakukan dengan istimewa dibandingkan yang lainnya.

MTI Canduang yang merupakan lembaga swasta dan mandiri, para pemimpinnya telah melaksanakan individual consideration. Semua staf dan karyawan diperlakukan secara profesional sesuai dengan SOP yang telah ditetapkan bersama oleh pimpinan madrasah dan tertulis lengkap pada RAPBM (Rencana Anggaran Pendapatan Belanja Madrasah). 
Dalam segi finansial misalnya, guru/karyawan yang lebih lama masa pengabdiannya akan menerima honor yang lebih besar dibandingkan dengan yang baru, karena akan mendapatkan tunjangan-tunjangan yang lebih banyak, di antaranya tunjangan hari tua, kesehatan, kesejahteraan dan sebagainya, serta setiap 2 tahun akan ada kenaikan gaji secara berkala. Begitu juga akan berbeda antara S2/S3 dengan yang masih S1 apalagi yang belum sarjana. Sedangkan informasi yang penulis dapatkan bahwasanya dulu guru atau karyawan yang masih keluarga besar Syeikh Sulaiman Arrasuli akan mendapatkan gaji yang lebih besar dari yang lainnya walaupun masih baru/belum sarjana, yang penting masih berasal dari keluarga besar Yayasan. Ini menunjukkan bahwasanya pimpinan yang ada di MTI Canduang adalah pimpinan yang transformasional, mampu membuat perubahan yang lebih baik dibandingkan dengan sebelumnya.

Begitu juga hasil wawancara yang Penulis peroleh sama persis dengan temuan di atas, dan Ust. Maiyunis, S.Ag mengatakan;

"Banyak perubahan yang terjadi di sini dalam beberapa tahun terakhir. Kalau dulu keluarga Syeikh Sulaiman Arrasuli mendapatkan perlakuan istimewa. Akan tetapi sekarang semua diperlakukan sama karena sudah ada SOP dan RAPBM yang dibentuk bersama. Guru yang berprestasi mendapatkan penghargaan dari lembaga, tunjangan bertambah dan sudah banyak guru yang telah lulus sertifikasi, termasuk saya sendiri. Saya berharap jajaran pimpinan akan lebih maksimal lagi dalam bekerja supaya semuanya merasa enak dan betah di sini"(Ust. Maiyunis : 16 September 2013).

Ada beberapa indikator keberhasilan kepemimpinan transformasional di MTI Canduang selain yang telah Penulis sebutkan di atas. Di antaranya adalah:

a. Jumlah siswa yang terus bertambah walaupun tidak signifikan.

a. Prestasi yang diraih terus menerus.

b. Akreditasi Madrasah. Untuk tingkat Aliyah terakreditasi "A". Sedangkan untuk tingkat Tsanawiyah baru terdaftar.

c. Rasionalisasi dan efektifitas struktur kepemimpinan.

Demi keefektifan dan keprofesionalan serta menjawab tuntutan zaman yang telah di atur oleh pemerintah. Maka struktur kepemimpinan yang ada di MTI Canduang mengalami perubahan dari sebelumnya.

Faktor-faktor pendukung keberhasilan kepemimpinan transformasional di MTI Canduang yang Penulis temukan di antaranya adalah sebagai berikut:

a. Jajaran pimpinan yang kuat serta dukungan yang solid dari bawahan.

Alasannya karena pemimpin yang ada dipilih dan diseleksi dengan ketat oleh Raisul Madrasah kemudian Yayasan Syeikh Sulaiman Arrasuli.

b. Kebanyakan pimpinan masih usia muda. Di usia mudalah biasanya orang ingin menunjukkan jati dirinya, serta usia muda identik dengan cekatan dan energik. Contohnya Kepala Aliyah Ust. Zulkifli, MA yang belum berusia 30 tahun, Kepala 
Tata Usaha dan Waka. Kesiswaan Ust Beni Kharisma Arrasuli, S.HI, LLM, yang baru selesai S-2.

c. Pimpinan yang berpengalaman. "Pengalaman adalah guru yang terbaik". Ungkapan tersebut memang benar adanya. Di MTI Canduang pimpinan yang ada rata-rata ahli dibidangnya dan kaya dengan pengalaman. Seperti Ketua Yayasan DR. Syukri Iska, M.Ag pernah menjadi Ketua STAIN Batusangkar selama dua periode. Begitu juga dengan Ust. Zulkifli, MA selaku Kepala Aliyah yang sebelumnya menjadi Waka Kurikulum serta gelar akademik yang disandangnya.

d. Dukungan dan partisipasi yang tinggi dari masyarakat.

Sebuah lembaga pendidikan biasanya didirikan oleh masyarakat, di tengahtengah masyarakat dan untuk kepentingan masyarakat. Lembaga yang maju dan tetap eksis ditengah-tengah masyarakat tentunya karena mendapatkan dukungan serta partisipasi yang tinggi dari masyarakat dan semua stakeholders yang ada. Begitu juga dengan MTI Canduang yang mendapat dukungan penuh dari masyarakat.

e. Dukungan dari wali murid.

Walaupun mayoritas dari wali murid merupakan masyarakat tingkat ekonomi menengah ke bawah, akan tetapi dukungan dan partisipasi dari mereka secara spiritual sangat besar. Bahkan dalam segi material mereka ikut mencari dana dan donatur untuk MTI Canduang.

f. Dukungan dari Pemerintah setempat.
Ada beberapa program Madrasah yang sumber dananya berasal dari Pemerintah setempat. Bukti nyata dukungan dari pemerintah adalah program fiqh unggulan dan tahfidzul Qur'an yang sepenuhnya dananya dari Pemerintah Kabupaten.

g. Lokasi Madrasah yang strategis.

Secara geografis lokasi Madrasah ini sangat strategis. MTI Canduang berada tidak jauh dari jalan lintas Sumatera Barat dan Riau yang dilalui oleh banyak masyarakat dan mudah dikunjungi kapanpun dan oleh siapapun yang melewati jalan lintas tersebut. Begitu juga jaraknya tidak terlalu jau dengan Kota Bukittinggi yang merupakan Kota Wisata.

h. Usia MTI Canduang yang relatif tua.

Tahun 2013 ini MTI Canduang genap berusia 85 tahun. Para alumninya sudah tersebar di mana-mana dan banyak yang menjadi pejabat pemerintahan dan tokoh masyarakat,seperti Prof. Dr. Makmur Syarif Rektor IAIN Imam Bonjol Padang, Fakhrori Umar Wakil Gubernur Jambi, Yosarfi Hutahuruf Walikota Sibolga Sumatera Utara dan lain-lain. Dengan demikian masyarakat akan termotivasi untuk menyekolahkan anaknya di MTI Canduang, karena alumninya bisa menjadi pejabat penting dan tokoh di lingkungan tempat tinggalnya.

Di samping adanya faktor-faktor pendukung kepemimpinan di MTI Canduang yang telah diuraikan di atas, Penulis juga mendapatkan beberapa sebab yang menjadi penghambat kelancaran kepemimpinan di 
MTI Canduang. Diantara penghambatpenghambat tersebut antara lain adalah:

a. Belum adanya asrama yang permanen dan kondusif

Di MTI Canduang asrama yang ada tidak bisa menampung semua santri yang jumlahnya mencapai 700 siswa lebih.

b. Keuangan Madrasah yang belum memadai. Dengan dana yang belum memadai sebuah lembaga tidak akan bisa berbuat banyak. Begitu juga dengan MTI Canduang yang dana keuangannya masih jauh dari yang diharapkan. Salah satu dampaknya adalah belum bisa membangun asrama yang permanen sehingga bisa menampung seluruh santri yang ada.

c. Rendahnya kemampuan ekonomi wali murid.

Wali murid di MTI Canduang rata-rata kemampuan ekonominya menengah ke bawah yang berdampak pada pembayaran SPP banyak yang nunggak, walaupun nominalnya sangat murah dibandingkan dengan SPP di pesantren maju lainnya pada umumnya.

d. Masih ada latar belakang guru yang berbeda dengan bidang studi yang diajarkan.

Beberapa guru yang seharusnya bisa disertifikasi terbentur oleh mata pelajaran yang diajarkan dengan sertifikat pendidikannya yang tidak sama. Padahal seharusnya bidang studi yang diajarkan harus sesuai dengan keahlian yang telah tertulis dan tertuang dalam ijazah yang telah disertifikat oleh pemerintah.
Sedangkan yang dimaksud dengan gaya kepemimpinan verbal di sini adalah bukti nyata tertulis yang dibuat sebelumnya oleh jajaran pimpinan yang ada di MTI Canduang dan berkaitan langsung dengan tugasnya sebagai seorang pemimpindan hasilnya sebagai berikut:

a. Adanya SOP Yayasan yang dibuat bersama oleh pimpinan di MTI Canduang.

b. Adanya RAPBM yang ditetapkan oleh Yayasan berdasarkan rancangan pimpinan di MTI Canduang.

c. Semua pimpinan yang ada telah membuat program kerjanya masing-masing sesuai dengan tugas dan fungsinya.

Sedangkan yang dimaksud dengan kepemimpinan non verbal di MTI Canduang adalah sikap dan tingkah laku (action) yang ditunjukkan oleh pimpinan-pimpinan yang ada di sana sehari-hari. Diantara kepemimpinan non verbal yang ditunjukkan oleh para pemimpin di MTI Canduangyang Penulisperoleh antara lain:

a. Pemimpin menjadi uswatunhasanah

b. Tegas dan disiplin

c. Peduli tarhadap bawahan

d. Bertanggung jawab

Mutu pendidikan yang ada di MTI Canduang sudah sesuai dengan BSNP (Badan Standar Nasional Pendidikan) yang memuat 8 SNP (Standar Nasional Pendidikan) yang harus dimiliki oleh sekolah formal di Indonesia, yaitu: 
a. Standar Isi

Di MTI Canduang baik tingkat Aliyah maupun tingkat Tsanawiyah, standar isi telah diatur dan ditetapkan bersama. Standar isi ini mencakup lingkup materi dan tingkat kompetensi untuk mencapai kompetensi lulusan pada jenjang dan jenis pendidikan tertentu. Standar Isi memuat kerangka dasar dan struktur kurikulum, beban belajar, kurikulum tingkat satuan pendidikan, dan kalender pendidikan/ akademik. Bahkan untuk kurikulum di MTI Canduang memadukan kurikulum yang telah ditetapkan oleh pemerintah dan ditambah dengan kurikulum MTI sendiri. Hal ini berdampak pada beban belajar yang lebih banyak.

b. Standar Proses

Proses pembelajaran di MTI Canduang diselenggarakan secara interaktif, inspiratif, menyenangkan, menantang, memotivasi peserta didik untuk berpartisipasi aktif, serta memberikan ruang yang cukup bagi prakarsa, kreatifitas, dan kemandirian sesuai dengan bakat, minat, dan perkembangan fisik serta psikologis peserta didik. Pendidik di MTI Canduang memberikan uswah dan qudwah hasanah.

c. Standar Kompetensi Lulusan

Standar kompetensi lulusan meliputi seluruh mata pelajaran yang mencakup sikap, pengetahuan, dan ketrampilan. Dengan demikian setiap tahunnya MTI Canduang mengeluarkan lulusan yang telah ditetapkan dan diatur oleh lembaga. d. Standar Pendidik dan Tenaga Kependidikan Kualifikasi Tenaga Pendidik dan Kependidikan di MTI Canduang sebagian besar telah memiliki sertifikat dan ijazah S1 sesuai dengan keahliannya yang telah diakui oleh pemerintah. Bahkan beberapa orang telah memiliki ijazah S2 dan sedang dalam proses mencapai gelar S3.

e. Standar Sarana dan Prasarana

Sarana yang dimiliki MTI Canduang meliputi perabot, peralatan pendidikan, media pendidikan, buku dan sumber belajar lainnya, bahan habis pakai, serta perlengkapan lain yang diperlukan untuk menunjang proses pembelajaran. MTI Canduangjuga memiliki prasarana yang meliputi lahan, ruang kelas, ruang pimpinan satuan pendidikan, ruang pendidik, ruang tata usaha, ruang perpustakaan, ruang laboratorium, kantin, instalasi daya dan jasa, tempat berolahraga, tempat ibadah, tempat bermain, dan ruang/tempat lain yang diperlukan untuk menunjang proses pembelajaran yang teratur dan berkelanjutan.

f. Standar Pengelolaan

Standar pengelolaan di MTI Canduang menerapkan manajemen berbasis sekolah yang ditunjukkan dengan kemandirian, kemitraan, partisipasi, keterbukaan, dan akuntabilitas.

g. Standar Pembiayaan

Pembiayaan pendidikan di MTI Canduang terdiri atas biaya investasi, biaya operasi, dan biaya personal. Biaya investasi meliputi penyediaan sarana dan prasarana, pengembangan sumber daya 
manusia, dan modal kerja tetap. Biaya personal meliputi biaya pendidikan yang harus dikeluarkan oleh peserta didik. Biaya operasi meliputi gaji pendidik dan tenaga kependidikan serta segala tunjangan yang melekat pada gaji, bahan atau peralatan pendidikan habis pakai, dan biaya operasi pendidikan tak langsung berupa daya, air, jasa telekomunikasi, pemeliharaan sarana dan prasarana, uang lembur, transportasi, konsumsi, pajak, asuransi dan lain-lain.

h. Standar Penilaian Pendidikan

Penilaian pendidikan di MTI Canduang terdiri atas: penilaian hasil belajar oleh pendidik, penilaian hasil belajar oleh satuan pendidikan, dan penilaian hasil belajar oleh Pemerintah.

\section{PENUTUP}

Dari temuan penelitian dan pembahasan di atas, akhirnya Penulis bisa menyimpulkan hal-hal penting yang berkaitan dengan kepemimpinan transformasional dalam peningkatan mutu pendidikan di MTI Canduang, diantaranya adalah:

1. Kepemimpinan transformasional dalam peningkatan mutu pendidikan di MTI Canduang ditunjukkan dengan beberapa poin. Di antaranya adalah:

a. Idealized Influenceyang dibuktikan dengan pemimpin yang ada di MTI Canduang dipilih dengan proses yang lama dan ketat, ahli dibidangnya, berpengalaman, muda, energik dan lain-lain. b. Inspirational Motivation yang ditunjukkan dengan kerja nyata dan adanya keberanian dari jajaran pimpinan di MTI Canduang dalam membuat terobosan-terobosan baru yang jarang dilakukan oleh pemimpin biasa.

c. Intelectual Stimulationyang ditunjukkan oleh pimpinan di MTI Canduang dalam menambah pengetahuan dan pengalaman bawahannya dengan mendatangkan para pakar dan ahli yang dibutuhkan di sana.

d. Individual Considerationdengan memperlakukan semua karyawan yang ada di MTI Canduang sesuai dengan SOP dan RAPBM yang telah ditetapkan bersama oleh pimpinan di sana tanpa mengistimewakan keluarga, kerabat dan teman dekat.

2. Faktor-faktor pendukung keberhasilan kepemimpinan transformasional dalam peningkatan mutu pendidikan di MTI Canduang diantaranya adalah:

a. Jajaran pimpinan yang kuat serta dukungan yang solid dari bawahan

b. Kebanyakan pimpinan masih usia muda

c. Pimpinan yang berpengalaman

d. Dukungan dan partisipasi yang tinggi dari masyarakat

e. Dukungan dari wali murid

f. Dukungan dari Pemerintah setempat

g. Lokasi Madrasah yang strategis

h. Usia MTI Canduang yang relatif tua 
Sedangkan yang menjadi penghambat kepemimpinan transformasional di MTI Canduang adalah:

a. Belum adanya asrama yang permanen dan kondusif yang bisa menampung semua santri

b. Keuangan Madrasah yang belum memadai

c. Rendahnya kemampuan ekonomi wali murid

d. Masih ada latar belakang guru yang berbeda dengan bidang studi yang diajarkan

3. Gaya kepemimpinan verbal Pemimpin di MTI Canduang ditunjukkan dengan adanya:

a. Adanya SOP yang dibuat bersama oleh pimpinan di MTI Canduang

b. Adanya RAPBM yang ditetapkan oleh jajaran pimpinan di MTI Canduang

c. Semua pimpinan yang ada telah membuat program kerjanya masingmasing sesuai dengan tugas dan fungsinya

Sedangkan gaya kepemimpinan non verbal pemimpin di MTI Canduang ditunjukkan dengan:

a. Pemimpin menjadi uswatunhasanah

b. Tegas dan disiplin c. Peduli tarhadap bawahan

d. Bertanggung jawab

4. Kepemimpinan transformasional telah dilaksanakan dengan baik di MTI Canduang, sehingga mutu pendidikan yang ada di sana semakin baik dan sesuai dengan delapan SNP yang telah diatur dalam Undang-undang.

\section{KEPUSTAKAAN ACUAN}

Aan Komariah dan Cepi Triana, Visionari Leadership Menuju Sekolah yang Efektif, Bandung: Bumi Aksara, 2010.

Encep Syafrudin Muhyi,Kepemimpinan Pendidikan Transformasional, Jakarta: Diadit Media Press, 2011.

Mujamil Qomar, Manajemen Pendidikan Islam, Jakarta: Erlangga, 2007.

Nurkholis, Manajemen Berbasis Sekolah, Jakarta: PT. Gramedia Widiasarana Indonesia, 2003.

Sayyid Ahmad Al-Hasyimi, Syarah Mukhtaarul Ahaadits, Bandung: Sinar Baru Algensindo, 2001.

Undang-undang RI Nomor 20 tahun 2003

Tentang sistem Pendidikan Nasional, 2003. 